\title{
On the Temperature Dependence of Hydrogen Evolution Reaction at Nickel Foam and Pd-Modified Nickel Foam Catalysts
}

\author{
Boguslaw Pierozynski • Tomasz Mikolajczyk
}

Published online: 17 July 2014

(C) The Author(s) 2014. This article is published with open access at Springerlink.com

\begin{abstract}
This communication reports on hydrogen evolution reaction (HER), studied at $\mathrm{Ni}$ foam and $\mathrm{Pd}$-activated nickel foam materials in $0.1-\mathrm{M} \mathrm{NaOH}$ solution over the temperature range of $20-60^{\circ} \mathrm{C}$. Catalytic modification of $\mathrm{Ni}$ foam leads to significant facilitation of temperature-dependent HER kinetics, manifested through radically reduced values of chargetransfer resistance parameter, as well as substantially modified Tafel polarization curves. The presence of a catalytic additive (Pd) is evidenced through scanning electron microscopy (SEM) analysis.
\end{abstract}

Keywords Nickel foam - Catalytic modification · HER . Electrochemical impedance spectroscopy

\section{Introduction}

Cathodic evolution of hydrogen at metal electrodes is one of the most significant electrochemical processes, especially important with respect to rapid development of proton exchange membrane (PEM) fuel cell and battery technologies. On the other hand, nickel makes one of the best non-noble catalyst materials suitable for hydrogen evolution reaction (HER) in alkaline media, primarily due to its high corrosion resistance at high $\mathrm{pH}$ values [1-5]. Nickel foams are made by chemical vapour deposition (CVD) [6], or electrochemical or electroless deposition method, typically with a polyurethane foam precursor [7]. Such-produced catalyst is characterized by high

B. Pierozynski $(\bowtie) \cdot$ T. Mikolajczyk

Department of Chemistry, Faculty of Environmental Management and Agriculture, University of Warmia and Mazury in Olsztyn, Plac Lodzki 4, 10-957 Olsztyn, Poland

e-mail: bogpierozynski@yahoo.ca

B. Pierozynski

e-mail: boguslaw.pierozynski@uwm.edu.pl porosity and specific surface area, and also by good electrical conductivity, high corrosion resistance and superior mechanical properties [7, 8]. Significant improvement of electrocatalytic properties of bare nickel foam (e.g. towards HER or oxidation of aliphatic alcohols) could be realized through surface deposition of nano-structured noble metals (e.g. Pd, $\mathrm{Ru}, \mathrm{Rh}, \mathrm{Pt}$ or their binary/ternary alloys). The above might be performed by means of electrodeposition, spontaneous deposition [8-10] or by chemical reduction processes, where the latter are typically facilitated with $\mathrm{NaBH}_{4}$, ethylene glycol, hydrazine or their compositions [11-15].

In this communication, Pd-activated nickel foam catalyst material was prepared via spontaneous deposition method [8], to produce cathode having superior HER performance for alkaline environments. The choice of palladium results from the fact that Pd element itself is well known to exhibit high electrochemical activity towards hydrogen absorption and evolution processes [16-21] with an exchange current density value of $1 \times 10^{-3} \mathrm{~A} \mathrm{~cm}^{-2}$, which is very close to that exhibited by $\mathrm{Pt}$ [18]. These properties of palladium along with highly porous, large surface area metallic Ni foam structure [22] make a Pd-modified nickel foam composite material a very good candidate for studying the HER behaviour.

\section{Experimental}

All solutions were prepared by means of a Direct-Q 3 UV ultra-pure water purification system from Millipore (18.2 $\mathrm{M} \Omega \mathrm{cm}$ water resistivity). A $0.1-\mathrm{M} \mathrm{NaOH}$ supporting solution was prepared from AESAR, $99.996 \% \mathrm{NaOH}$ pellets. An electrochemical cell, made of Pyrex glass, was used during the course of this work. The cell comprised three electrodes: a Ni-foam-based working electrode (WE) in a central part, a reversible $\mathrm{Pd}$ (0.5-mm-diameter wire of $99.9 \%$ purity, Aldrich) 
hydrogen electrode (RHE) as reference and a Pt (1.0-mmdiameter wire of $99.9998 \%$ purity, Johnson Matthey, Inc.) counter electrode (CE), both placed in separate compartments. The procedures for cleaning the cell and preparation of the CE/RHE electrodes for the measurements were as previously described in Pierozynski and Smoczynski [23], Pierozynski [24] and Pierozynski [25]. Before conducting the HER experiments, each $\mathrm{Ni}$ foam electrode was also activated in $0.1 \mathrm{M} \mathrm{NaOH}$ by cathodic polarization, carried out at $20 \mathrm{~mA}$ for $300 \mathrm{~s}$ in order to maintain surface area reproducibility [26].

Nickel foam was supplied by MTI Corporation (>99.99\% Ni, thickness $1.6 \mathrm{~mm}$, surface density $346 \mathrm{~g} \mathrm{~m}^{-2}$, porosity $\geq 95 \%$ ). All electrodes were $1 \mathrm{~cm} \times$ $1 \mathrm{~cm}$, for which pure $\mathrm{Ni}$ foam accounted for about $2.6 \mathrm{~cm}^{2}$ of geometrical area and $0.030 \mathrm{~g}\left(\sim 88 \mathrm{~cm}^{2} \mathrm{~g}^{-1}\right)$. Spontaneous deposition of Pd catalyst on nickel foam samples was performed according to the corresponding description given in Verlato et al. [8]. Hence, freshly cut foam samples were subjected to acetone and $\mathrm{CH}_{2} \mathrm{Cl}_{2}$ wash (15 min +ultrasonication), following air drying and acid etching in $2 \mathrm{M} \mathrm{HCl}\left(15 \mathrm{~min}\right.$ at $\left.60^{\circ} \mathrm{C}\right)$. Then, spontaneous deposition of metal catalyst was realized by dipping pretreated foam electrodes in $0.005 \mathrm{M} \mathrm{PdCl}_{2}(\mathrm{pH} 1.0$, $t_{\text {dep. }}=15-300 \mathrm{~s}$, temperature $25 \pm 1{ }^{\circ} \mathrm{C}$ ) to produce Pdactivated $\mathrm{Ni}$ foam catalyst material. Working electrode assemblies were made by mechanically attaching $\mathrm{Ni}$ foam/Pd-modified Ni foam samples to 0.5 -mm-diameter $\mathrm{Ni}$ wire (Aldrich, $\geq 99.9 \%$ ). In addition, shrinkable PE or PTFE sleeves were used to provide Pd wire insulation within the electrochemical cell.

A.c. impedance spectroscopy and quasi steady state polarization techniques were employed during the course of this work. All measurements were performed over the temperature range of $20-60{ }^{\circ} \mathrm{C}$ (controlled by laboratory water bath) by means of the Solartron 12,608 W Full Electrochemical System, consisting of 1260 frequency response analyser (FRA) and 1287 electrochemical interface (EI) for an a.c. signal of $5 \mathrm{mV}$ and the frequency range sweep between $1.0 \times 10^{5}$ and $0.5 \times 10^{-1} \mathrm{~Hz}$. The instruments were controlled by ZPlot 2.9 or Corrware 2.9 software for Windows (Scribner Associates, Inc.), whereas data analysis was performed with ZView 2.9 (Corrview 2.9) software package. The impedance spectra were fitted by means of a complex, non-linear, least squares immitance fitting program, LEVM 6, written by J.R. Macdonald [27]. In addition, quasi-potentiostatic cathodic polarization experiments (recorded at a scan rate of $0.5 \mathrm{mV} \mathrm{s}^{-1}$ ) for the HER were carried out at all examined $\mathrm{Ni}$ foam electrodes. Also, an appropriate correction was introduced [28], in order to account for a small but significant temperature shift of the Pd RHE over the studied temperature range of $20-60{ }^{\circ} \mathrm{C}$.
Spectroscopic characterization of Pd-activated $\mathrm{Ni}$ foam electrodes was performed by means of Quanta FEG 250 scanning electron microscope (SEM). In addition, powder X-ray diffraction (XRD) technique was employed to determine average size of Pd crystallite domains for the selected Pd-modified Ni foam samples. The XRD spectra were recorded by means of Siemens D500 powder diffractometer with $\mathrm{Cu} \mathrm{K}_{\alpha}$ radiation $(\lambda=$ $1.5418 \AA, U=38 \mathrm{kV}, I=30 \mathrm{~mA})$ in a standard BraggBrentano mode without sample spinning. Experimentally recorded data were analysed by means of the phase analysis XRAYAN software.
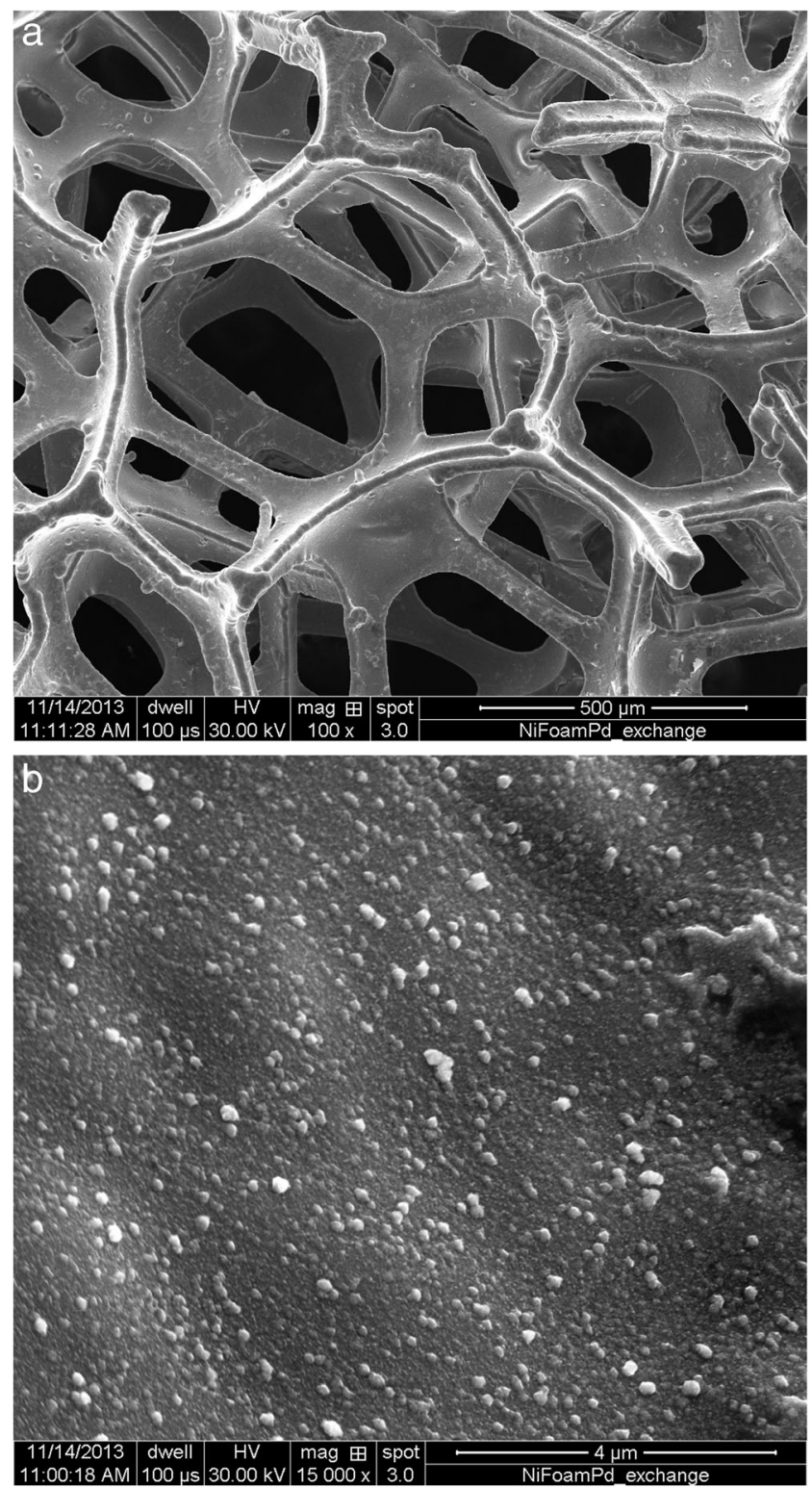

Fig. 1 a SEM micrograph picture of Pd-modified Ni foam surface ( $\sim 0.1 \mathrm{wt} \%$ Pd), taken at $\times 100$ magnification; b As in Fig. 1a, but taken at $\times 15,000$ magnification 
Fig. 2 XRD pattern for spontaneously deposited Pd element on nickel foam substrate, where observed diffraction lines correspond to the following sequence of fcc indices: (111), (200), (220), (311) and (222) for both Ni and Pd elements

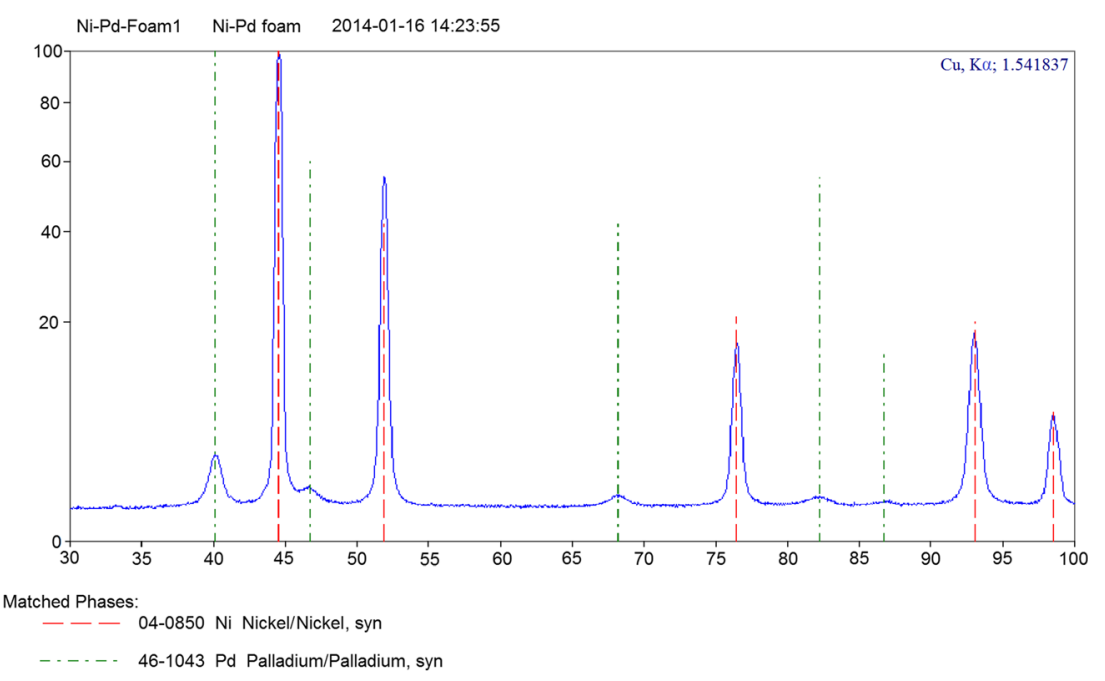

\section{Results and Discussion}

\section{SEM and XRD Characterizations of Pd-Modified Ni Foam} Electrode

Figure 1a, b illustrates the effect of spontaneous deposition of palladium at a very low level $(\sim 0.1 \mathrm{wt} \% \mathrm{Pd})$ on the MTI foam, recorded for the magnifications of $\times 100$ and $\times$ 15,000 , respectively. Hence, at the magnification of $\times$ 15,000, high-density and homogeneously distributed small Pd nuclei could clearly be seen in Fig. 1b. The SEM-approximated Pd grain size value came to $10.0 \pm$

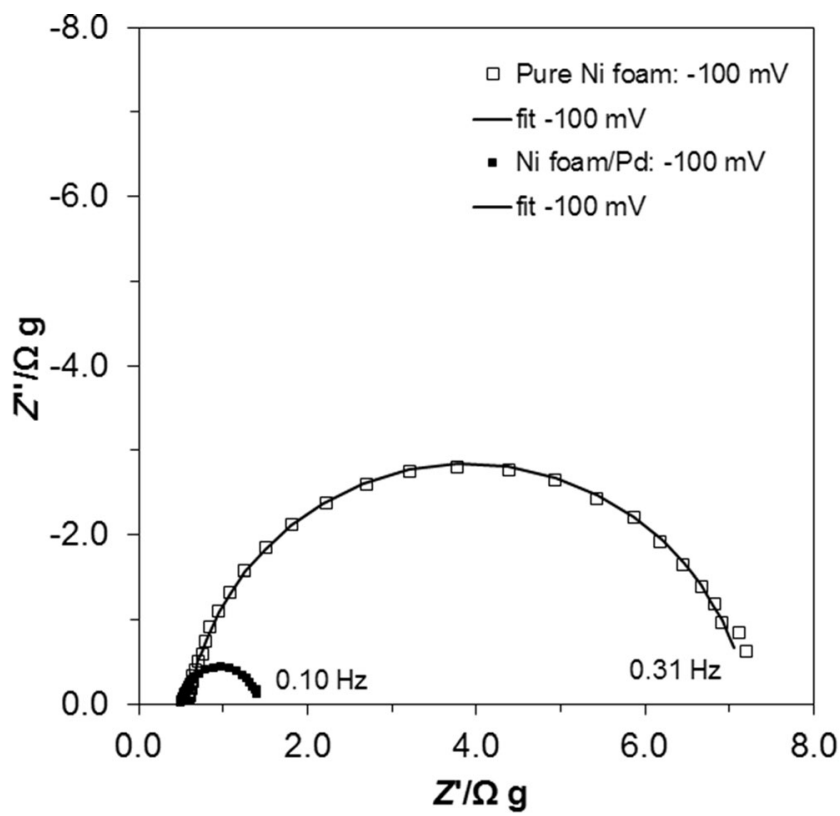

Fig. 3 Complex-plane impedance plots for the HER on pure and Pdmodified $\mathrm{Ni}$ foam electrode surfaces in contact with $0.1 \mathrm{M} \mathrm{NaOH}$, recorded at room temperature for $-100 \mathrm{mV}$ (vs RHE). The solid lines correspond to representation of the data according to the equivalent circuit shown in Fig. 4
$1.0 \mathrm{~nm}$. The above was performed through utilization of the Image Analysis Program (NIS-Elements Basic Research on Nikon), based on an analogous procedure to that described in detail in Smoczyński et al. [29]. In addition, the powder-XRD-calculated average $\mathrm{Pd}$ grain size value came to $7.0 \pm 0.7 \mathrm{~nm}$ (see Fig. 2 above). Measurements were carried out based on the Scherrer's method, which correlates the size of crystallite domains with relative widening of diffraction peaks (see Pecharsky and Zavalij [30] for further details).

A.c. Impedance Behaviour of HER on Pure and Pd-Modified Ni Foam Materials in $0.1 \mathrm{M} \mathrm{NaOH}$

A.c. impedance characterization of the HER on pure Ni foam and catalyst (Pd)-modified Ni foam electrodes in $0.1 \mathrm{M} \mathrm{NaOH}$ is shown in Fig. 3 and Tables 1, 2 and 3. Hence, the impedance-examined, both unmodified and Pd-activated $\mathrm{Ni}$ foam electrodes exhibited single, "depressed" semicircles (a single-step charge-transfer reaction) at all examined potentials and reaction temperatures, in the explored frequency range (please note that a high-frequency semicircle electrode porosity response, which is typically observed in alkaline media, was practically indiscernible). Examples of Nyquist impedance plots, recorded for pure and the Pd-modified nickel foam electrodes at $-100 \mathrm{mV}$ versus RHE, are shown in Fig. 3 below. The overpotential dependence of Faradaic reaction resistance $\left(R_{\mathrm{ct}}\right)$ and double-layer capacitance $\left(C_{\mathrm{dl}}\right)$ parameters for the HER, examined over the temperature range of 20 $60{ }^{\circ} \mathrm{C}$ at pure nickel foam (derived based on a constant phase element (CPE)-modified Randles equivalent circuit model shown in Fig. 4) is presented in Table 1. The CPE element was used in the circuit in order to account for the capacitance dispersion [31, 32] effect, represented by somewhat distorted semicircles in the Nyquist impedance plots. 
Table 1 Electrochemical parameters for the HER on cathodically activated pure Ni foam electrode in contact with $0.1 \mathrm{M} \mathrm{NaOH}$, studied over the temperature range of $20-60{ }^{\circ} \mathrm{C}$

\begin{tabular}{|c|c|c|c|c|c|}
\hline \multirow[t]{2}{*}{$E / \mathrm{mV}$} & \multicolumn{5}{|l|}{$R_{\mathrm{ct}} / \Omega \mathrm{g}$} \\
\hline & $20^{\circ} \mathrm{C}$ & $30^{\circ} \mathrm{C}$ & $40^{\circ} \mathrm{C}$ & $50^{\circ} \mathrm{C}$ & $60^{\circ} \mathrm{C}$ \\
\hline-50 & $13.653 \pm 0.066$ & $3.759 \pm 0.037$ & $1.822 \pm 0.014$ & $1.226 \pm 0.009$ & $0.844 \pm 0.007$ \\
\hline-100 & $6.674 \pm 0.022$ & $3.134 \pm 0.011$ & $1.439 \pm 0.006$ & $0.939 \pm 0.004$ & $0.761 \pm 0.004$ \\
\hline-150 & $2.353 \pm 0.012$ & $1.653 \pm 0.008$ & $0.757 \pm 0.004$ & $0.556 \pm 0.003$ & $0.496 \pm 0.003$ \\
\hline-200 & $0.877 \pm 0.008$ & $0.777 \pm 0.004$ & $0.391 \pm 0.003$ & $0.311 \pm 0.002$ & $0.317 \pm 0.002$ \\
\hline-250 & $0.464 \pm 0.008$ & $0.402 \pm 0.003$ & $0.236 \pm 0.003$ & $0.207 \pm 0.003$ & $0.216 \pm 0.002$ \\
\hline-300 & $0.289 \pm 0.005$ & $0.248 \pm 0.002$ & $0.171 \pm 0.003$ & $0.155 \pm 0.003$ & $0.149 \pm 0.003$ \\
\hline-350 & $0.209 \pm 0.005$ & $0.187 \pm 0.004$ & $0.143 \pm 0.004$ & $0.121 \pm 0.003$ & $0.120 \pm 0.003$ \\
\hline-400 & $\begin{array}{l}0.162 \pm 0.003 \\
C_{\mathrm{dl}} / \mu \mathrm{F} \mathrm{g} \mathrm{g}^{-1} \mathrm{~s}^{\varphi 1-1}\end{array}$ & $0.141 \pm 0.003$ & $0.107 \pm 0.002$ & $0.097 \pm 0.002$ & $0.089 \pm 0.002$ \\
\hline-50 & $10,959 \pm 104$ & $10,316 \pm 227$ & $10,262 \pm 267$ & $11,852 \pm 374$ & $11,959 \pm 379$ \\
\hline-100 & $8,608 \pm 81$ & $8,694 \pm 118$ & $8,371 \pm 201$ & $8,319 \pm 181$ & $10,125 \pm 264$ \\
\hline-150 & $6,545 \pm 157$ & $6,771 \pm 158$ & $6,348 \pm 221$ & $6,520 \pm 268$ & $8,363 \pm 345$ \\
\hline-200 & $4,931 \pm 256$ & $5,560 \pm 183$ & $5,049 \pm 243$ & $5,048 \pm 316$ & $6,726 \pm 242$ \\
\hline-250 & $5,019 \pm 501$ & $4,914 \pm 259$ & $4,436 \pm 375$ & $4,958 \pm 510$ & $6,568 \pm 523$ \\
\hline-300 & $4,011 \pm 445$ & $4,570 \pm 352$ & $4,371 \pm 516$ & $5,274 \pm 654$ & $5,614 \pm 666$ \\
\hline-350 & $3,680 \pm 596$ & $5,350 \pm 779$ & $7,376 \pm 1,134$ & $6,068 \pm 892$ & $9,690 \pm 1,308$ \\
\hline-400 & $3,806 \pm 495$ & $4,544 \pm 680$ & $5,166 \pm 607$ & $5,448 \pm 591$ & $5,668 \pm 939$ \\
\hline
\end{tabular}

The results were obtained by fitting the CPE-modified Randles (Fig. 4) equivalent circuit to the experimentally obtained impedance data (reproducibility usually below $5 \%, \chi^{2}=3 \times 10^{-4}$ to $2 \times 10^{-3}$ )

Table 2 Electrochemical parameters for the HER on Pd-modified $\mathrm{Ni}$ foam electrode in contact with $0.1 \mathrm{M} \mathrm{NaOH}$, studied over the temperature range of $20-60{ }^{\circ} \mathrm{C}$

\begin{tabular}{|c|c|c|c|c|c|}
\hline \multirow[t]{2}{*}{$E / \mathrm{mV}$} & \multicolumn{5}{|l|}{$R_{\mathrm{ct}} / \Omega \mathrm{g}$} \\
\hline & $20^{\circ} \mathrm{C}$ & $30^{\circ} \mathrm{C}$ & $40^{\circ} \mathrm{C}$ & $50^{\circ} \mathrm{C}$ & $60^{\circ} \mathrm{C}$ \\
\hline-50 & $1.526 \pm 0.013$ & $0.310 \pm 0.006$ & $0.273 \pm 0.007$ & $0.195 \pm 0.003$ & $0.151 \pm 0.002$ \\
\hline-100 & $0.928 \pm 0.007$ & $0.373 \pm 0.005$ & $0.284 \pm 0.003$ & $0.198 \pm 0.001$ & $0.156 \pm 0.001$ \\
\hline-150 & $0.564 \pm 0.004$ & $0.344 \pm 0.006$ & $0.253 \pm 0.006$ & $0.175 \pm 0.002$ & $0.143 \pm 0.003$ \\
\hline-200 & $0.370 \pm 0.003$ & $0.258 \pm 0.003$ & $0.209 \pm 0.003$ & $0.150 \pm 0.001$ & $0.128 \pm 0.002$ \\
\hline-250 & $0.263 \pm 0.003$ & $0.199 \pm 0.003$ & $0.170 \pm 0.002$ & $0.129 \pm 0.002$ & $0.115 \pm 0.002$ \\
\hline-300 & $0.198 \pm 0.003$ & $0.154 \pm 0.002$ & $0.135 \pm 0.002$ & $0.108 \pm 0.001$ & $0.102 \pm 0.002$ \\
\hline-350 & $0.157 \pm 0.003$ & $0.126 \pm 0.003$ & $0.112 \pm 0.003$ & $0.095 \pm 0.001$ & $0.094 \pm 0.004$ \\
\hline-400 & $\begin{array}{l}0.128 \pm 0.002 \\
C_{\mathrm{dl}} / \mu \mathrm{F} \mathrm{g}^{-1} \mathrm{~s}^{\varphi 2-1}\end{array}$ & $0.105 \pm 0.002$ & $0.095 \pm 0.001$ & $0.080 \pm 0.001$ & $0.078 \pm 0.001$ \\
\hline-50 & $204,554 \pm 2,577$ & $283,856 \pm 14,760$ & $303,933 \pm 13,038$ & $229,245 \pm 11,920$ & $217,082 \pm 11,288$ \\
\hline-100 & $188,395 \pm 2,826$ & $216,844 \pm 7,372$ & $197,812 \pm 6,329$ & $178,624 \pm 5,680$ & $191,293 \pm 8,225$ \\
\hline-150 & $168,942 \pm 3,209$ & $195,436 \pm 8,403$ & $202,904 \pm 12,782$ & $174,723 \pm 10,133$ & $183,216 \pm 15,023$ \\
\hline-200 & $166,952 \pm 4,340$ & $192,497 \pm 6,737$ & $190,181 \pm 7,797$ & $174,156 \pm 7,662$ & $161,856 \pm 8,254$ \\
\hline-250 & $157,458 \pm 5,983$ & $182,805 \pm 9,652$ & $187,070 \pm 10,288$ & $184,273 \pm 11,424$ & $167,292 \pm 11,041$ \\
\hline-300 & $157,822 \pm 9,153$ & $169,185 \pm 9,474$ & $171,439 \pm 10,252$ & $181,095 \pm 13,401$ & $189,936 \pm 18,993$ \\
\hline-350 & $166,592 \pm 14,660$ & $171,318 \pm 16,446$ & $182,083 \pm 16,933$ & $154,350 \pm 13,274$ & $246,764 \pm 39,482$ \\
\hline-400 & $162,506 \pm 10,563$ & $186,372 \pm 14,350$ & $177,697 \pm 12,972$ & $157,085 \pm 11,153$ & $182,815 \pm 14,076$ \\
\hline
\end{tabular}

The results were obtained by fitting the CPE-modified Randles (Fig. 4) equivalent circuit to the experimentally obtained impedance data (reproducibility usually below $5 \%, \chi^{2}=1 \times 10^{-4}$ to $3 \times 10^{-3}$ ) 
Table 3 Exchange current density, Tafel slope and activation energy electrochemical parameters for the HER, obtained on pure $\mathrm{Ni}$ foam and Pd-modified Ni foam electrodes in contact with $0.1 \mathrm{M} \mathrm{NaOH}$ over the temperature range of $20-60{ }^{\circ} \mathrm{C}$

\begin{tabular}{|c|c|c|c|c|c|}
\hline \multicolumn{6}{|l|}{ Pure Ni foam } \\
\hline $\begin{array}{l}\text { Parameter } \\
j_{\mathrm{o}} / \mathrm{A} \mathrm{cm}^{-2}\end{array}$ & $20^{\circ} \mathrm{C}$ & $30^{\circ} \mathrm{C}$ & $40^{\circ} \mathrm{C}$ & $50^{\circ} \mathrm{C}$ & $60^{\circ} \mathrm{C}$ \\
\hline $\begin{array}{l}\text { A.c. } \\
\text { impedance: }\end{array}$ & $1.2 \times 10^{-6}$ & - & - & - & $2.0 \times 10^{-5}$ \\
\hline Tafel plots: & $9.8 \times 10^{-7}$ & $2.3 \times 10^{-6}$ & $4.6 \times 10^{-6}$ & $7.7 \times 10^{-6}$ & $1.2 \times 10^{-5}$ \\
\hline$b_{\mathrm{c}} / \mathrm{mV} \mathrm{dec}{ }^{-1}$ & -137 & -169 & -183 & -193 & -222 \\
\hline$E_{\mathrm{A}} / \mathrm{kJ} \mathrm{mol}^{-1}$ & $\begin{array}{l}-100 \mathrm{mV} \\
45.4\end{array}$ & $\begin{array}{l}-200 \mathrm{mV} \\
24.1\end{array}$ & $\begin{array}{l}-300 \mathrm{mV} \\
14.6\end{array}$ & $\begin{array}{l}-400 \mathrm{mV} \\
12.7\end{array}$ & \\
\hline \multicolumn{6}{|c|}{ Pd-modified Ni foam } \\
\hline$j_{0} / \mathrm{A} \mathrm{cm}^{-2}$ & $20^{\circ} \mathrm{C}$ & $30^{\circ} \mathrm{C}$ & $40^{\circ} \mathrm{C}$ & $50{ }^{\circ} \mathrm{C}$ & $60{ }^{\circ} \mathrm{C}$ \\
\hline $\begin{array}{l}\text { A.c. } \\
\text { impedance: }\end{array}$ & $1.3 \times 10^{-5}$ & - & - & - & $1.4 \times 10^{-4}$ \\
\hline Tafel plots: & $8.6 \times 10^{-6}$ & $1.1 \times 10^{-5}$ & $1.7 \times 10^{-5}$ & $2.1 \times 10^{-5}$ & $5.3 \times 10^{-5}$ \\
\hline$b_{\mathrm{c}} / \mathrm{mV} \mathrm{dec}^{-1}$ & -65 & -76 & -74 & -79 & -97 \\
\hline$E_{\mathrm{A}} / \mathrm{kJ} \mathrm{mol}^{-1}$ & $\begin{array}{l}-100 \mathrm{mV} \\
34.3\end{array}$ & $\begin{array}{l}-200 \mathrm{mV} \\
21.6\end{array}$ & $\begin{array}{l}-300 \mathrm{mV} \\
13.6\end{array}$ & $\begin{array}{l}-400 \mathrm{mV} \\
10.2\end{array}$ & \\
\hline
\end{tabular}

Thus, for the cathodically activated $\mathrm{Ni}$ foam electrodes, the recorded $R_{\text {ct }}$ parameter examined at $20{ }^{\circ} \mathrm{C}$ decreased from $13.653 \Omega \mathrm{g}$ at $-50 \mathrm{mV}$ to $0.162 \Omega \mathrm{g}$ at the potential of $-400 \mathrm{mV}$ versus RHE. Simultaneously, the $C_{\mathrm{dl}}$ parameter significantly reduced from 10,959 to $3,806 \mu \mathrm{F} \mathrm{g}^{-1} \mathrm{~s}^{\varphi 1-1}$ (2.9 times) for the same potential range. The latter effect most likely results from partial blocking of electrochemically active electrode surface by freshly formed $\mathrm{H}_{2}$ bubbles. The above might easily be visualized for a complex Ni foam electrode structure (Fig. 1a, b), especially at significant overpotentials. Also, when the capacitance value of $10,959 \mu \mathrm{F} \mathrm{g}^{-1} \mathrm{~s}^{\varphi 1-1}$ (recorded for electrode weight of $35.0 \mathrm{mg}$ at $-50-\mathrm{mV} \mathrm{RHE}$ ) is referred to that commonly used value of $20 \mu \mathrm{F} \mathrm{cm}{ }^{-2}$ in literature for smooth and homogeneous surfaces [33, 34], electrochemically active surface area of the Ni foam electrode could roughly be estimated at $19.2 \mathrm{~cm}^{2}$ (or $548 \mathrm{~cm}^{2} \mathrm{~g}^{-1}$ ). Similar impedance behaviour (with a single-step

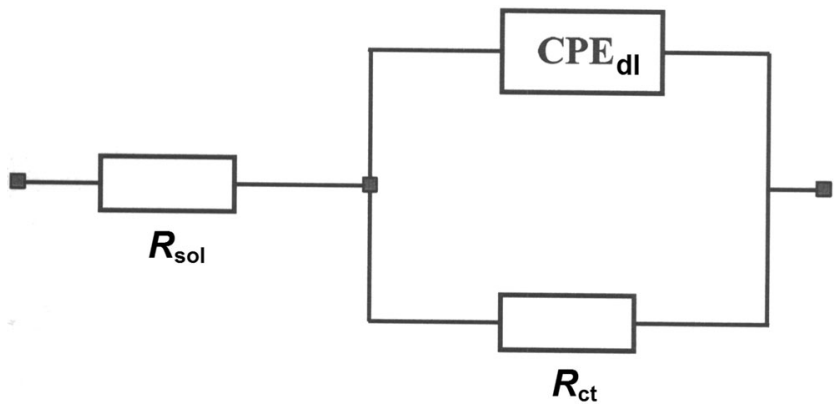

Fig. 4 Equivalent circuit model used for fitting the impedance data for both pure and Pd-modified $\mathrm{Ni}$ foam electrodes, obtained in $0.1 \mathrm{M} \mathrm{NaOH}$. The circuit includes a constant phase element (CPE) for distributed capacitance; $R_{\mathrm{ct}}$ and $C_{\mathrm{dl}}$ (as $\mathrm{CPE}_{\mathrm{dl}}$ ) elements correspond to the HER charge-transfer resistance and double-layer capacitance components, and $R_{\text {sol }}$ is solution resistance charge-transfer process) has recently been presented by Grden et al. [35] for the HER characterization of Incofoam ${ }^{\circledR} \mathrm{Ni}$ foam commercial product in $0.5-\mathrm{M} \mathrm{KOH}$ solution. There, the recorded at $-200-\mathrm{mV} R_{\mathrm{ct}}$ parameter value for an etched foam sample came to $43 \Omega(\sim 1.30 \Omega \mathrm{g})$, which is significantly higher than $0.877 \Omega \mathrm{g}$ recorded for analogous conditions in Table 1. Simultaneously, the impedance-approximated [35] specific surface area for the etched Incofoam ${ }^{\circledR}$ sample came to $241 \mathrm{~cm}^{2} \mathrm{~g}^{-1}$, as compared to that of $548 \mathrm{~cm}^{2} \mathrm{~g}^{-1}$ for the MTI foam examined in this work. These results suggest that the latter nickel foam provides significantly enhanced electrochemical properties towards the HER (most likely due to its unique porous structure), as compared to the former one. In another recent work by van Drunen et al. [36], cyclic-voltammetry-derived values of electrochemically active surface area for analogous $\mathrm{Ni}$ foam material were on the order of $250-450 \mathrm{~cm}^{2} \mathrm{~g}^{-1}$. Other important options for the fabrication of highly-porous, three-dimensional $\mathrm{Ni}$ or Ni-originated matrices include powder-based [37,38] and electrochemical deposition processes [10, 39]. As all options are significant, nickel foam comparatively provides a fully commercialized technology with highly reproducible material having superior mechanical and electrical properties.

Table 1 also presents the temperature dependence of the $R_{\mathrm{ct}}$ and $C_{\mathrm{dl}}$ electrochemical parameters, studied over the temperature range of $20-60{ }^{\circ} \mathrm{C}$. Hence, for the two temperature extremes, 20 and $60{ }^{\circ} \mathrm{C}$, the recorded charge-transfer resistance exhibited significant reduction, correspondingly from 13.653 to $0.844 \Omega \mathrm{g}$ (by 16.2 times) at $-50 \mathrm{mV}$ and from 0.162 to $0.089 \Omega \mathrm{g}$ (by 1.8 times) at $-400 \mathrm{mV}$. Furthermore, the $C_{\mathrm{dl}}$ parameter recorded at individual overpotentials kept slowly rising upon temperature increase (see Table 1). The above could be explained in terms of extended access to the catalytic 
Fig. 5 Linear plots of $-\log R_{\mathrm{ct}}$ in function of potential (vs RHE), obtained for the HER performed on pure and $\mathrm{Pd}$-modified $\mathrm{Ni}$ foam electrodes in $0.1-\mathrm{M} \mathrm{NaOH}$ solution, recorded at 20 and $60{ }^{\circ} \mathrm{C}$. Symbols represent experimental results and lines are data fits

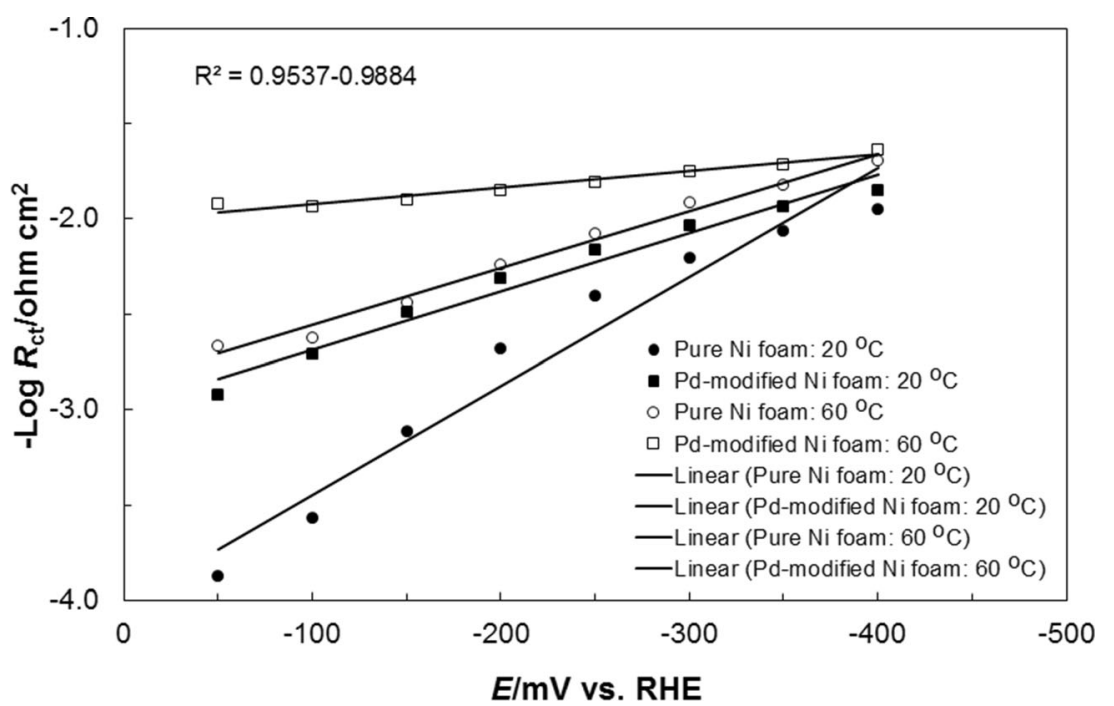

surface within the porous electrode structure at elevated temperatures. In addition, higher temperatures should considerably facilitate hydrogen bubble removal.

On the other hand, the recorded charge transfer resistance parameter for the Pd-modified $\mathrm{Ni}$ foam electrode at $20{ }^{\circ} \mathrm{C}$ ranged from 1.526 to $0.128 \Omega \mathrm{g}$ for the overpotential range of 50-400-mV RHE (see Table 2). The above means considerable reduction of the $R_{\mathrm{ct}}$ parameter (as compared to those $R_{\mathrm{ct}}$ values recorded for the unmodified $\mathrm{Ni}$ foam surface), namely by 8.9 times and 1.3 times at -50 and $-400 \mathrm{mV}$, respectively. In addition, deposition of catalytic Pd nano-structure resulted in significant enhancement of electrochemically available surface area, as compared to that of the nickel foam baseline material. Thus, for the Pd-activated $\mathrm{Ni}$ foam, the recorded values of the $C_{\mathrm{d} 1}$ parameter at $-50-\mathrm{mV}$ RHE came to 204,554 $\mu \mathrm{F} \mathrm{g}^{-1} \mathrm{~s}^{\varphi 2-1}$ (about 10,228 $\mathrm{cm}^{2} \mathrm{~g}^{-1}$ ). The above is $\sim 18.7$ times greater than that recorded for the baseline $\mathrm{Ni}$ foam cathode. Understandably, for the catalyst-modified nickel foam material, the $C_{\mathrm{d} 1}$ parameter exhibited similar (decreasing) overpotential dependence to that recorded for the baseline Ni foam electrode. However, the recorded $C_{\mathrm{dl}}$ ratio for the $-50 /-400-\mathrm{mV}$ pair came to $\sim 1.3$, which was radically smaller than that recorded for the unmodified $\mathrm{Ni}$ foam electrode above (2.9 times). In other words, on the Pdmodified nickel foam, the HER predominantly proceeds on the catalyst-covered outer parts of the foam structure, so that the removal of hydrogen bubbles from the catalyst becomes strongly facilitated.

Correspondingly, Table 2 above shows the temperature dependence of the $R_{\mathrm{ct}}$ and $C_{\mathrm{dl}}$ parameters, examined over the temperature range of $20-60{ }^{\circ} \mathrm{C}$ for the $\mathrm{Pd}$-modified $\mathrm{Ni}$ foam electrode. Thus, the recorded (at 20 and $60{ }^{\circ} \mathrm{C}$ ) chargetransfer resistance exhibited significant reduction, respectively from 1.526 to $0.151 \Omega \mathrm{g}$ (by 10.1 times) at $-50 \mathrm{mV}$ and from 0.128 to $0.078 \Omega \mathrm{g}$ (by 1.6 times) at $-400 \mathrm{mV}$. Then, the $C_{\mathrm{dl}}$ parameter recorded at specific overpotentials also continued increasing upon rising temperature (see Table 2 and compare with the corresponding results presented in Table 1 above).

Finally, dimensionless $\varphi_{1}$ and $\varphi_{2}$ parameters of the CPE circuit (see Fig. 4 and Tables 1 and 2), where $\varphi$ determines the constant phase angle in the complex-plane plot, $(0 \leq \varphi \leq 1)$ varied between $0.83-0.97$ and $0.82-0.94$, respectively.
Fig. 6 Linear plots of $-\log R_{\mathrm{ct}}$ versus $T^{-1}$ for the HER performed on pure and Pd-modified Ni foam electrodes in $0.1-\mathrm{M} \mathrm{NaOH}$ solution, at the stated overpotential values

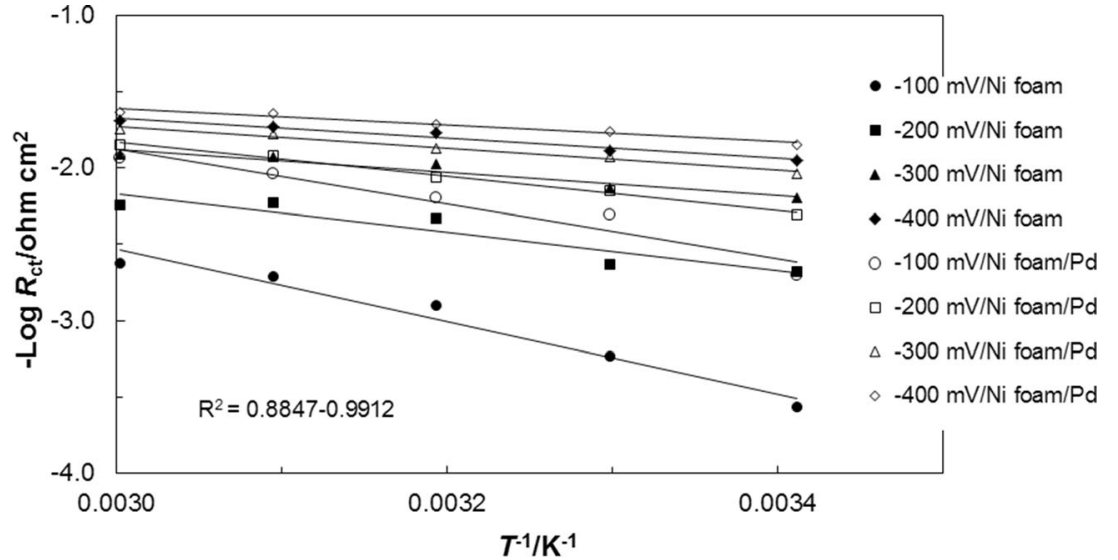


Fig. 7 Quasi-potentiostatic cathodic Tafel polarization curves (recorded at a rate of $0.5 \mathrm{mV} \mathrm{s}^{-1}$ ) for the HER on pure and Pdmodified $\mathrm{Ni}$ foam electrode surfaces, carried out in $0.1-\mathrm{M}$ $\mathrm{NaOH}$ solution at 20 and $60^{\circ} \mathrm{C}$ (appropriate $i R$ correction was made based on the solution resistance derived from the impedance measurements)

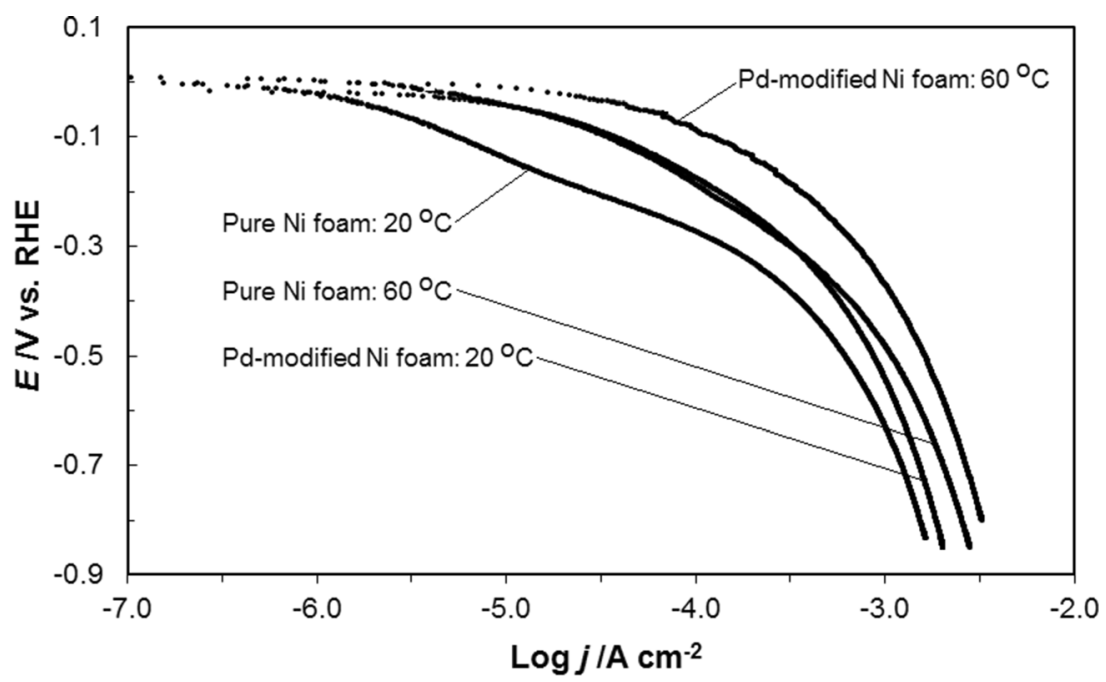

Based on the linear relationship-log $R_{\text {ct }}$ versus overpotential (for kinetically controlled reactions), exhibited here over the overpotential range of 50-400 $\mathrm{mV}$ versus RHE (see Fig. 5 above), the exchange currentdensities for the HER were calculated based on the Butler-Volmer equation and through utilization of the relation between the exchange current density $\left(j_{0}\right)$ and the $R_{\text {ct }}$ parameter for overpotential approaching zero value [5, 40-42]. Hence, the impedance-derived values of the $j_{0}$ parameter came to $1.2 \times 10^{-6} \mathrm{~A} \mathrm{~cm}^{-2}$ (at $20^{\circ} \mathrm{C}$ ) and $2.0 \times$ $10^{-5} \mathrm{~A} \mathrm{~cm}^{-2}$ (at $60{ }^{\circ} \mathrm{C}$ ) for the unmodified $\mathrm{Ni}$ foam, whereas significantly increased $j_{0}$ values, namely, $1.3 \times$ $10^{-5} \mathrm{~A} \mathrm{~cm}^{-2}$ (at $20^{\circ} \mathrm{C}$ ) and $1.4 \times 10^{-4} \mathrm{~A} \mathrm{~cm}^{-2}$ (at $60{ }^{\circ} \mathrm{C}$ ), were recorded for the $\mathrm{Pd}$-modified nickel foam catalyst material (see Table 3 for details). The room-temperaturederived HER exchange current density value $(1.3 \times$ $10^{-5} \mathrm{~A} \mathrm{~cm}^{-2}$ ) for the Pd-activated nickel foam is significantly higher than the $j_{0}$ for bulk $\mathrm{Ni}\left(6.3 \times 10^{-6} \mathrm{~A} \mathrm{~cm}^{-2}\right)$, but dramatically lower than the corresponding bulk $j_{0}$ parameter value for $\mathrm{Pd}$ element $\left(1 \times 10^{-3} \mathrm{~A} \mathrm{~cm}^{-2}\right)$ [18]. However, it should be understood that electrocatalytic activity of a catalyst material strongly depends on the extent of its electrochemically active surface area and nano-structural properties. One should also note that nano-scaled catalytic structures typically demonstrate far superior electrocatalytic activities to those exhibited by the respective bulk catalyst materials. Thus, highly modifiable (e.g. by deposition of variable, but negligible amount of $\mathrm{Pd}$ ), large surface area porous $\mathrm{Ni}$ foam could potentially produce exceptionally active and relatively inexpensive HER catalyst.

In addition, Fig. 6 presents $-\log R_{\mathrm{ct}}$ versus $T^{-1}$ Arrhenius-type plots, constructed based on the $R_{\mathrm{ct}}=\mathrm{f}(T)$ impedance results, presented for the overpotential range of $100-400 \mathrm{mV}$ versus RHE for the pure and the Pdactivated Ni foam catalyst electrodes. Thus-obtained experimental electrochemical energies of activation, $E_{\mathrm{A}}$ $\left[\mathrm{kJ} \mathrm{mol}^{-1}\right]$ for the HER on the Pd-modified nickel foam,
Fig. 8 Temperature dependence of experimental Tafel charge transfer coefficient for the HER on pure and Pd-modified foam electrodes in contact with $0.1-\mathrm{M}$ $\mathrm{NaOH}$ solution

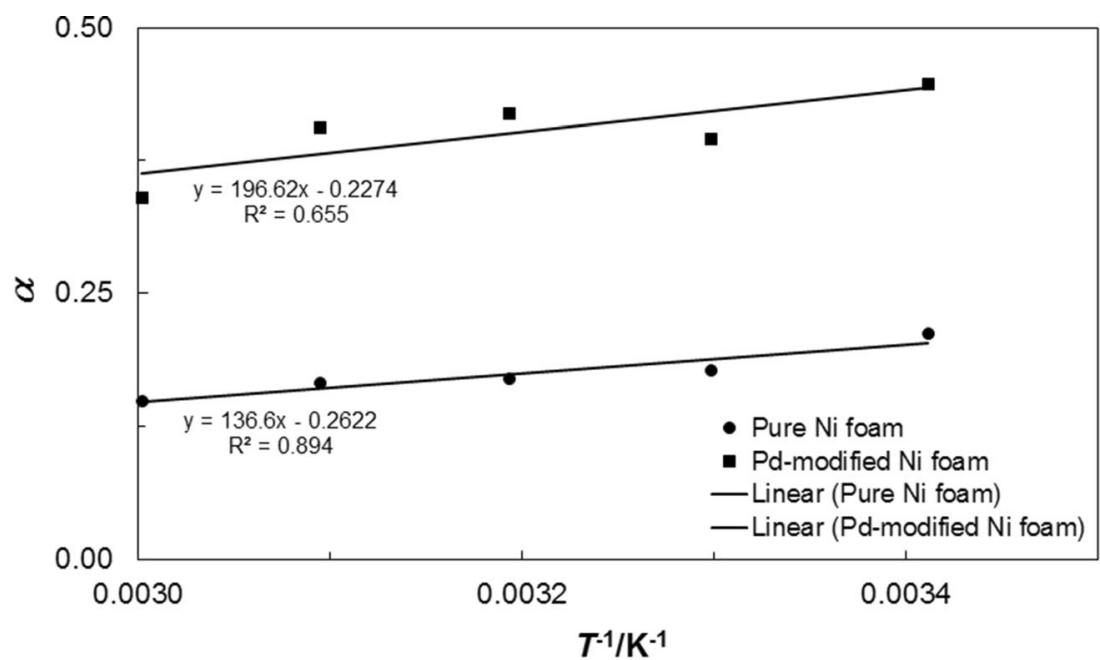


came significantly lower (by $\sim 25 \%$ at $-100 \mathrm{mV}$ and by $20 \%$ at $-400 \mathrm{mV}$ ) than those for the bare $\mathrm{Ni}$ foam electrode (Table 3).

HER Characterization by Steady State Tafel Polarization Plots

The kinetic results discussed above are in good agreement with these of the potentiostatic Tafel polarizations, presented for the pure and the Pd-modified Ni foam HER catalysts (performed at 20 and $60^{\circ} \mathrm{C}$ ) in Fig. 7. In fact, radical enhancement of the HER performance upon introduction of catalytic amount of Pd into Ni foam structure could clearly be observed over the kinetically controlled, low-overpotential region in this figure. The recorded cathodic Tafel slopes (parameter $b_{\mathrm{c}}$ in Table 3) exhibited significant temperature dependence (see Conway [43] for details) for both examined electrode materials. Hence, for the temperature range of $20-60{ }^{\circ} \mathrm{C}$, the Tafel slope changed from -137 to $-222 \mathrm{mV} \mathrm{dec}{ }^{-1}$ and from -65 to $-97 \mathrm{mV} \mathrm{dec}{ }^{-1}$ for the baseline Ni foam and the Pd-modified Ni foam catalyst materials, respectively. At the same time, considerable reduction of the cathodic Tafel slope for the palladium-activated $\mathrm{Ni}$ foam came in-line with significant facilitation of the exchange current density parameter. Thus, the Tafel-based values of the $j_{0}$ parameter for the HER reached $9.8 \times 10^{-7}$ (at $20^{\circ} \mathrm{C}$ ) and $1.2 \times 10^{-5} \mathrm{~A} \mathrm{~cm}^{-2}$ (at $60{ }^{\circ} \mathrm{C}$ ) for the unmodified $\mathrm{Ni}$ foam, and $8.6 \times 10^{-6}$ (at $20^{\circ} \mathrm{C}$ ) and $5.3 \times$ $10^{-5} \mathrm{~A} \mathrm{~cm}^{-2}$ (at $60{ }^{\circ} \mathrm{C}$ ) for the Pd-modified nickel foam electrode (see other details in Table 3). These results are in a fairly good agreement with the impedance-derived values of the $j_{0}$ parameter. However, the recorded difference between the Tafel-calculated and the impedance-derived values of the exchange current density parameter in Table 3 (especially perceptible for the Pd-modified Ni foam electrode) could possibly result from somewhat inferior quality of the Tafel fit for this case. It should be stated here that all calculated in this work exchange current-densities and cathodic Tafel slopes for the HER are within the range that is commonly quoted for Ni-porous entities in literature. Hence, Dominguez-Crespo et al. have recently reported [38] Tafel slopes in the range $152-214 \mathrm{mV} \mathrm{dec}^{-1}$ and optimum $j_{0}$ value of $6.3 \times 10^{-5} \mathrm{~A} \mathrm{~cm}^{-2}$ for highly porous $(\mathrm{La}, \mathrm{Ce}) / \mathrm{Ni}$ electrodes. Furthermore, Vazquez-Gomez et al. [10] reported for cathodically deposited porous Ni layer onto Ni disk electrode a Tafel slope of $138 \mathrm{mV} \mathrm{dec}-1$ and a respective $j_{0}$ value equal to $3.2 \times$ $10^{-4} \mathrm{~A} \mathrm{~cm}^{-2}$, whereas further Ru or Ir modifications (by spontaneous metal depositions) resulted there (generally) in reduction of Tafel slopes and a dramatic increase (by 7-38 times) of the $j_{0}$ parameter (see Table 3 in Vazquez-Gomez [10] and compare with the results presented above). Similar trends for the recorded $b_{\mathrm{c}}$ and $j_{0}$ parameters (including their temperature dependence) were also reported [39] for threedimensional porous Ni structures, fabricated over the so- called double-template electrochemical deposition process (see Table 2, Herraiz-Cardona [39]).

In addition, as originally argued by Conway [43] (based on non-linear $T$ dependence of the $b_{\mathrm{c}}$ Tafel slope), the recorded charge transfer coefficient $\alpha$ linearly decreased with rising temperature [44] for both examined HER catalyst materials (see Fig. 8 above).

\section{Conclusions}

Palladium nano-deposit (at $\sim 0.1 \mathrm{wt} \%$ ) on the surface of cathodically activated $\mathrm{Ni}$ foam material significantly enhanced catalytic activity of baseline foam material towards cathodic evolution of hydrogen in $0.1-\mathrm{M} \mathrm{NaOH}$ solution. The above was specifically observed over kinetically controlled, low-overpotential range, being a result of superior HER activity of a catalytic Pd additive, in addition to the resultant, extensive modification of electrochemically active surface for this catalyst material.

Both Tafel slopes, as well as charge transfer coefficient, exhibited temperature-dependent behaviour. Significant facilitation of the HER performance for the Pd-modified Ni foam material was revealed through considerably reduced Tafel slopes and electrochemical energies of activation, and by substantially increased values of exchange current density parameter, as compared to those obtained for the unmodified nickel foam cathode. Finally, the results obtained in this work indicated substantial opportunities for Ni-foam-modified cathode materials in commercial alkaline water electrolysers.

Open Access This article is distributed under the terms of the Creative Commons Attribution License which permits any use, distribution, and reproduction in any medium, provided the original author(s) and the source are credited.

\section{References}

1. B.E. Conway, B.V. Tilak, Adv. Catal. 38, 1 (1992)

2. J.Y. Huot, L. Brossard, Int. J. Hydrog. Energy 12(12), 821 (1987)

3. H.E.G. Rommal, P.J. Morgan, J. Electrochem. Soc. 135(2), 343 (1988)

4. D.M. Soares, O. Teschke, I. Torriani, J. Electrochem. Soc. 139(1), 98 (1992)

5. N. Krstajic, M. Popovic, B. Grgur, M. Vojnovic, D. Sepa, J. Electroanal. Chem. 512, 16 (2001)

6. V. Paserin, S. Marcuson, J. Shu, D.S. Wilkinson, Adv. Eng. Mater. 6, 454 (2004)

7. S. Inazawa, A. Hosoe, M. Majima, K. Nitta, Sci. Technol. Rev 71, 23 (2010)

8. E. Verlato, S. Cattarin, N. Comisso, A. Gambirasi, M. Musiani, L. Vazquez-Gomez, Electrocatal 3, 48 (2012)

9. I. Bianchi, E. Guerrini, S. Trasatti, Chem. Phys. 319, 192 (2005) 
10. L. Vazquez-Gomez, S. Cattarin, P. Guerriero, M. Musiani, Electrochim. Acta 53, 8310 (2008)

11. P. Kim, J.B. Joo, W. Kim, J. Kim, I.K. Song, J. Yi, J. Power Sources 160, 987 (2006)

12. Y. Suo, I.M. Hsing, J. Power Sources 196, 7945 (2011)

13. A. Dutta, S.S. Mahapatra, J. Datta, Int. J. Hydrog. Energy 36, 14898 (2011)

14. R.M. Modibedi, T. Masombuka, M.K. Mathe, Int. J. Hydrog. Energy 36, 4664 (2011)

15. B. Beyribey, B. Corbacioglu, Z. Altin, G. U. J. Sci. 22(4), 351 (2009)

16. S.Y. Qian, B.E. Conway, G. Jerkiewicz, Int. J. Hydrog. Energy 25, $539(2000)$

17. J.M. Skowroński, A. Czerwiński, T. Rozmanowski, Z. Rogulski, P. Krawczyk, Electrochim. Acta 52, 5677 (2007)

18. J.K. Norskov, T. Bligaard, A. Logadottir, J.R. Kitchin, J.G. Chen, S. Pandelov, U. Stimming, J. Electrochem. Soc. 152(3), J23 (2005)

19. T.H. Yang, S.I. Pyun, J. Electroanal. Chem. 414, 127 (1996)

20. T.G. Kelly, S.T. Hunt, D.V. Esposito, J.G. Chen, Int. J. Hydrog. Energy 38, 5638 (2013)

21. A. Pozio, S. Tosti, Handbook of Membrane Reactors: Reactor Types and Industrial Applications, Woodhead Publishing Ltd., Cambridge 16, 607 (2013)

22. J. Banhart, Prog. Mater. Sci. 46, 559 (2001)

23. B. Pierozynski, L. Smoczynski, J. Electrochem. Soc. 156(9), B1045 (2009)

24. B. Pierozynski, Int. J. Electrochem. Sci. 6, 63 (2011)

25. B. Pierozynski, Int. J. Hydrog. Energy 38, 7733 (2013)

26. Z. Xie, P. He, L. Du, F. Dong, K. Dai, T. Zhang, Electrochim. Acta 88, 390 (2013)

27. J.R. Macdonald, Electrochim. Acta 35, 1483 (1990)

28. A. Prokopowicz, M. Opallo, Solid State Ionics 157, 209 (2003)
29. L. Smoczyński, H. Ratnaweera, M. Kosobucka, M. Smoczyński, Sep. Purif. Technol. 122, 412 (2014)

30. V. Pecharsky, P. Zavalij, Fundamentals of Powder Diffraction and Structural Characterization of Materials, Springer, $2^{\text {nd }}$ edition, New York, 2009

31. T. Pajkossy, J. Electroanal. Chem. 364, 111 (1994)

32. B.E. Conway, B. Pierozynski, J. Electroanal. Chem. 622, 10 (2008)

33. A. Lasia, A. Rami, J Appl. Electrochem. 22, 376 (1992)

34. L. Chen, A. Lasia, J. Electrochem. Soc. 138, 3321 (1991)

35. M. Grdeń, M. Alsabet, G. Jerkiewicz, ACS Appl. Mater. Interfaces 4, $3012(2012)$

36. J. van Drunen, B. Kinkead, M.C.P. Wang, E. Sourty, B.D. Gates, G. Jerkiewicz, ACS Appl. Mater. Interfaces 5, 6712 (2013)

37. C. Hitz, A. Lasia, J. Electroanal. Chem. 500, 213 (2001)

38. M.A. Dominguez-Crespo, A.M. Torres-Huerta, B. Brachetti-Sibaja, A. Flores-Vela, Int. J. Hydrog. Energy 36, 135 (2011)

39. I. Herraiz-Cardona, E. Ortega, L. Vazquez-Gomez, V. Perez-Herranz, Int. J. Hydrog. Energy 37, 2147 (2012)

40. J.G. Highfield, E. Claude, K. Oguro, Electrochim. Acta 44, 2805 (1999)

41. R.K. Shervedani, A.R. Madram, Electrochim. Acta 53, 426 (2007)

42. S. Martinez, M. Metikos-Hukovic, L. Valek, J. Mol. Catal. A Chem. 245, 114 (2006)

43. B.E. Conway, in Modern Aspects of Electrochemistry, ed. by B.E. Conway, R.E. White, J.O’M. Bockris, Plenum Press, New York 16, 103 (1985)

44. G.E. Badea, I. Maior, A. Cojocaru, I. Corbu, Rev. Roum. Chim. 52(12), 1123 (2007) 